\title{
"Who Can Be Added": The Effects of Refugee Status Determination and Third Country Resettlement Processes on the Marriage Strategies, Rites, and Customs of the Southern Sudanese in Cairo
}

\author{
Lorraine Currie
}

\section{Abstract}

This study, based on ethnographic research, examines how refugee status determination and third country resettlement processes influence the marriage practices of the southern Sudanese refugee community in Cairo. The study showed that because of their inability to attain socio-economic integration into the host community combined with the growing insecurity of the environment of Cairo for refugees, many southern Sudanese have had to reevaluate their traditional marriage practices and family values to qualify for resettlement and escape to a better life. For example, the expectation of resettlement can directly affect courtship strategies, dowry payments, and couples' decisions regarding having children. Guidelines of UNHCR and/or resettlement countries play a considerable role in these decisions, as do rumours about marriage certification and difficulty in finding suitable partners in the West. In some instances, marriage becomes a business arrangement to secure resettlement. Refugee status denial sometimes has a negative impact on marriage, with spouses blaming each other for performing badly at the status determination interview, leading in some cases to violence and divorce. Sudanese youth with denied refugee status have particular difficulties as their hopes for a brighter future are dashed and with it their prospects of a normal family life.

\section{Résumé}

Cette étude, basée sur la recherche ethnographique, examine comment la détermination du statut de réfugié et le processus de réinstallation dans un pays tiers influencent les pratiques en matière du mariage dans la communauté de réfugiés de Soudanais du sud vivant au Caire.

L'étude a démontré qu'en raison de leur incapacité d'atteindre l'intégration socio-économique dans la communauté d'accueil et de l'insécurité grandissante de l'environnement du Caire pour les réfugiés, beaucoup de Soudanais du sud ont dû revoir leurs pratiques traditionnelles entourant le mariage ainsi que leurs valeurs familiales afin de satisfaire aux critères d'égibilité pour la réinstallation et pouvoir accéder à une vie meilleure. Par exemple, l'espoir de la réinstallation peut directement affecter les stratégies pour faire la cour, les paiements de la dot et les décisions des couples quant au fait d'avoir des enfants. Les directives du HCR et/ou des pays de réinstallation, ainsi que les rumeurs concernant la certification de mariage et la difficulté à trouver des partenaires convenables à l'Ouest, jouent un rôle considérable dans ces décisions. Dans certains cas, le mariage devient un arrangement d'affaires dans le but d'obtenir le droit de réinstallation. Le refus du statut de réfugié a quelquefois un impact négatif sur le mariage, avec les époux se reprochant mutuellement d'avoir fait mauvaise figure à l'interview de détermination de statut, menant dans certains cas à la violence et au divorce. Les jeunes soudanais, à 
qui le statut de réfugié a été refusé, présentent des difficultés particulières, vu que leurs espoirs d'un avenir plus brillant sont anéantis et avec cela leurs perspectives d'une vie familiale normale.

\section{Introduction}

"Who can be added" through marriage to the file of a person recognized as a refugee under the United Nations High Commissioner for Refugees (UNHCR) mandate in the context of Cairo's considerable refugee population has become a security and livelihood issue for the exiled southern Sudanese community, who are on the margins of and unable to integrate into Egyptian society. Reservations entered by Egypt to the UN Convention relating to the Status of Refugees (1951) severely restrict refugees from exercising their socio-economic rights. ${ }^{1}$ Refugees, even if born in Egypt, are not eligible for citizenship. The Four Freedoms reciprocal agreement signed in 2004 ostensibly granting Sudanese and Egyptian nationals freedom of movement, residence, work, and ownership of property in each other's countries is yet to be fully implemented. As a result of these constraints, at the time of this study, third-country resettlement was seen as the only durable solution for this group of people. Voluntary repatriation was not a feasible option until January 2005 with the conclusion of the comprehensive peace agreement between the Sudanese government and the Sudan's Peoples' Liberation Movement. ${ }^{2}$ Furthermore, in the aftermath of the attack of September 11, 2001, the outlet of resettlement to Western countries was practically suspended, which created a huge backlog that was not cleared until 2004. This resulted in a larger, more visible Sudanese refugee population in Cairo, in turn leading to a series of police raids and detentions. The situation of the Sudanese refugee community in Cairo was further exacerbated by the earlier 1997 UNHCR urban refugee policy, which limited assistance and promoted self-reliance of urban refugees on the basis of budget cuts, and not on protection issues.

Although the Canadian and Australian embassies in Cairo do resettle around one thousand closed file cases per year through their private sponsorship and family reunification programs, official recognition by UNHCR under the Refugee Convention for the most part is required to meet the resettlement criteria. Thus, marriage to someone eligible for resettlement has become one of the only remaining options for those who fall under the local integration category or for closed file cases to qualify for resettlement. ${ }^{3}$ The quest to be "added" amid the insecure and hostile environment of Cairo is beginning to impact marital relations.

This paper considers the effects of refugee status determination (RSD) and third-county resettlement processes on the marital strategies, rites, and customs of the southern Sudanese refugee community in Cairo. There is a paucity of academic research on the subject of refugees living in large urban agglomerates in the developing world. Previous studies of marriage among Sudanese populations have focused on how displacement in general has influenced marriage practices, rather than on specific variables such as RSD and resettlement procedures. By adding a different dimension using an "urban refugee" framework, this study aims to contribute new information and insight that will complement existing refugee literature, as well as stimulate interest in refugee issues that require further exploration. Furthermore, this research hopes to offer UNHCR and its resettlement partners in Cairo a more full-bodied understanding of the impact their policies have on the culture and behaviour of refugee communities, and subsequently this paper attempts to inform policy.

This paper is based on research that was conducted in Cairo over a six-month period in 2003 under the auspices of Forced Migration and Refugee Studies Program of the American University in Cairo. The study yielded qualitative data from semi-structured interviews with twenty-two southern Sudanese men and women; interviews with UNHCR, embassy and NGO officials; and participant observation. ${ }^{4}$ The research findings are analyzed under the different stages of the marriage cycle, namely: Courtship and Choice of Partner, Dowry Payment and Marriage Ceremonies, Marital Life and Children, and Divorce and Remarriage. Here the term "refugee" is used in it broadest sense at times to include "asylum seekers" and "displaced persons" who are living in refugee-type situations. Pseudonyms have replaced the real names of the refugees cited in this paper.

\section{Southern Sudanese Refugees in Cairo}

Between 1998 and 2005, UNHCR Regional Office in Cairo (RO Cairo) received a total of 78,916 asylum applications, of which 32,996 were recognized and 19,409 were resettled to a third country. From 1998 to 2002, the overall recognition rate fluctuated between 24 and 42 per cent, rising to 63 per cent in 2003. The marked increase in the recognition rate was linked to RO Cairo's decision to apply a wider interpretation of the Organization of African Unity (OAU) Convention definition in the RSD process. Presently, those accepted under the Refugee Convention are eligible for resettlement, while those accepted under the OAU Convention are settled in Egypt. At the end of 2005, there were 18,946 refugees registered with UNHCR in Egypt. The majority of the recognized refugees were from Sudan (71 per cent) and Somalia (21 per cent). The remaining 8 per cent was composed of some thirty-three other nationalities, mainly from Africa. 
The gender ratio of the refugee population was 61 per cent male and 39 per cent female; 34 per cent were children under the age of eighteen. There were also 11,000 asylum seekers registered with RO Cairo (mainly of Sudanese origin), whose refugee status had yet to be determined. ${ }^{5}$

Egypt is state party to the 1951 Refugee Convention and its 1967 protocol as well as the OAU Convention of 1969. Despite Egypt's formal commitment to refugee protection, the country has no domestic refugee legislation for governing asylum and has essentially delegated RSD and the welfare of refugees to UNHCR. At the time of this study, applying for asylum in Cairo could take up to fourteen months, as the UNHCR was overburdened and underfunded. ${ }^{6}$ Currently, the whole process takes about three months, as RSD has been suspended for Sudanese. The suspension of RSD for Sudanese started in mid-2004, pending the outcome of the peace agreement. Presently, Sudanese applicants are registered and granted temporary protection. $^{7}$

RO Cairo provides recognized refugees and Sudanese asylum seekers with medical care and educational grants for their children. Only the most vulnerable refugees and asylum seekers receive small monthly subsistence allowances. Refugees who meet the established resettlement criteria, such as the inability to integrate locally, extreme vulnerability, or protection problems that cannot be resolved in Egypt, are referred to one of RO Cairo's resettlement partners, which include the US, Australia, Canada, and Finland. ${ }^{8}$ As UNHCR recognition guarantees some level of assistance, protection, and the possibility of resettlement, it is not surprising that at the evaluation of a mental health workshop held in Cairo in 1999 for refugees and their caregivers (the catalyst for the workshop being the attempted suicide of a Sudanese man after being denied refugee status) that I helped organize and evaluate, refugees ranked application for RSD and resettlement to UNHCR and embassies as the most stressful experience facing them in Cairo. It exceeded even the daily struggle for livelihood.

In Egypt, refugees are not housed in camps, but live in rented apartments dispersed throughout the impoverished areas of Cairo where they join the host community in competing for limited services and jobs. ${ }^{9}$ However, refugees are unable to access subsistence, work, state education, and national health care on the same basis as nationals because of reservations entered by Egypt to the Refugee Convention. ${ }^{10}$ Furthermore, as Egyptian citizenship is granted by way of the patrilineal bloodline, refugees and their children, even if born in Egypt, are unable to attain citizenship. ${ }^{11}$ Despite the passing of a ministerial degree in 1992 granting refugee and asylum-seeking children access to state schools, this has not been realized due to linguistic and cultural differences, bureaucratic barriers, and absorptive capacity. Some 4,200 refugee children attend informal schools run primarily by churches. These schools are operating at full capacity and are unable to accommodate all refugee children. It is estimated that 1,200 refugee and asylum-seekers' children living in Cairo are not in school. ${ }^{12}$

Refugees can only secure jobs in the informal economy where they are often subject to exploitation. Most of their disposable income is used to cover rent costs, as refugees are charged high foreign rent rates, which leads to overcrowding and ultimately poor health. ${ }^{13}$ Refugees' UNHCR allowances combined with their income are still insufficient to meet their basic needs. ${ }^{14}$ Women are able to find work more easily than men. Many Sudanese women work as housemaids for Egyptian families, while their husbands stay at home looking after the children. Meanwhile, for the men, who are accustomed to being the breadwinners in Sudan, the reversal in gender roles has put severe strain on marital relations. Some women have had to resort to prostitution and the illegal brewing of alcohol in order to supplement the family's income in order to survive. ${ }^{15}$ In addition to these hardships, African refugees in Cairo are often subject to police checks and arrests, and for those with closed files there is the constant threat of being detained and the possibility of deportation back to Sudan. ${ }^{16}$

Owing to the vast cultural and religious differences between southern Sudanese and Egyptians the likelihood of their integrating into Egyptian society and attaining a sustainable livelihood is extremely low. For these reasons, the preferred durable solution for this group in the past was resettlement to a third country. ${ }^{17}$ In fact, in 2001, the US expanded its resettlement program in Cairo "primarily to address the needs of the southern Sudanese refugees in Egypt"18 However, heightened security checks in the aftermath of the attack of September 11,2001, practically put on hold refugee resettlement from Cairo, which only resumed to previous levels after several years. Consequently, the already overstretched UNHCR had even more people to assist with the same amount of resources. ${ }^{19}$ The effects of the earlier 1997 UNHCR urban policy, which resulted in their becoming even more marginalized and impoverished, further compounded the situation of refugees. ${ }^{20}$ The delay in resettlement also resulted in a larger, more visible refugee population in Cairo, which led to more frequent and intense police raids and detentions.

In 2003, the police became more overtly discriminatory; nearly two hundred Sudanese, most of them southerners, were picked up from the streets in a two-day roundup, referred to by the police officers involved as "Operation Track Down Blacks." Most of those arrested were under the protection of UNHCR. ${ }^{21}$ These raids were preceded by an 
article written in an Egyptian newspaper the previous week entitled "The Flood of Africans and Asians Who Steal the Bread from the Mouths of Our Unemployed Youth.” The article claimed, "Most of them deal in drugs or practice immoral activities" and come to Egypt because it is "believed to be a secure place where there is no religious or racial discrimination." 22 Still, this article and the police raids must be examined against the backdrop of Egypt's ailing economy, high unemployment rates, and spiraling population growth. ${ }^{23}$ This situation was exacerbated by the refusal of Western nations to burden-share and open their doors to large numbers of refugees in the aftermath of the September 11 attack. ${ }^{24}$

It was in this climate that my visit to Cairo in April 2003 took place, and during informal discussions with the Sudanese community, where the themes of marriage, RSD, and resettlement kept cropping up, I became increasingly aware of their interconnection. The impact that these processes were having on marital life became clear to me as I attended a school party and watched a play held there. Under the title "Who Can Be Added," a group of Sudanese children acted out a series of sketches on how to "add" people to a UNHCRrecognized file. Each scene on how to "add" revolved around a marriage theme such as a hastily arranged marriage that included a payment for the privilege of marrying someone with a recognized file; a hastily arranged divorce that allowed a new marriage to someone accepted by the UNHCR; or the pretence that a second wife was a sister in order that she could also be resettled with the rest of the family. Hence the title and subject for my research study was born.

\section{Courtship and Choice of Partner}

Although the southern Sudanese are a wide ethnic mix of people, they share some similarities when it comes to choosing a marriage partner. The three common characteristics they share are exogamy, pre-arranged marriages, and polygamous marriages. As the southern Sudanese marry to build alliances and create social ties with other families, the parents and extended family are very much involved in the choosing of a suitable marriage partner for their children. ${ }^{25}$ Although a few of the refugees I spoke with said that RSD and resettlement did not influence Sudanese refugees in Egypt when it came to choosing a partner, most of the interviewees believed that they were interconnected to a greater or lesser extent. The attitudes towards the scope and depth of the influence varied among the research participants. "To me it doesn't matter if someone is accepted by UNHCR and will travel, but to others it really makes a difference," one young refugee man told me. "In my experience only some families look to marry for this resettlement," said another refugee woman.
The refugees I met with went on to tell me about the courtship strategies developed by some of the Sudanese youth in Cairo in relation to RSD and resettlement. Godfrey, a thirty-three-year-old single man who came to Cairo in 1989 to study medicine on an Egyptian scholarship for Sudanese, and was unable to return to Sudan due to war, described the courtship "policy" being adopted by some of his friends with closed files:

People like us [with closed files] who have been in Cairo for a long time and who are exhausted from the life here look for a girl who is UNHCR accepted. You approach a girl who has recently come from Sudan so as she does not get the impression that you are after her for her UNHCR status. You then try to start a relationship before she applies to the UNHCR. If she gets accepted then you can make the commitment and be added to her file and travel abroad. Not all do it this way, others they wait and find out who has been recently accepted and then they begin the courtship. But sometimes if the girl gets accepted she will get rid of you and add another. It depends on how much you have convinced her of your love.

However, single young women have also developed some strategies of their own in their quest to be "added." Although pre-marital sexual relations and pregnancy bring shame and dishonour for a southern Sudanese girl and her family, ${ }^{26}$ several of the interviewees said that this was happening more in Egypt than in Sudan. Pio, a thirty-sevenyear-old married man whose teenage daughter works for an Egyptian employer, described the reasons for this behavioural change:

Some of our girls are alone here in Cairo, often their parents have been killed in the war. They experience many problems with the Egyptians they work for. They are often insulted and beaten. Even some of our girls have been raped and thrown from the balcony. The Egyptian family then claims she killed herself. If she has been denied status then she gets desperate and begins to look for a boy who will travel. If she fears the boy is not really serious she will get pregnant to make it a sure thing. The boy then feels obliged to add her to his file.

Nonetheless, it must be highlighted that the reverse can also happen. The refugees I spoke with explained that some Sudanese girls are intentionally getting pregnant by boys with closed files, and one refugee woman explained the rationale behind this practice:

Sometimes a girl is in love with a man, but he a closed file, and because the family of the girl is also rejected there is no way out for them. They try and force her to marry someone else who is 
UNHCR accepted. Sometimes the girl will just get pregnant to the one she loves, and goes to his house to live without the permission of the family.

Several of the interviewees talked about how some of the youth are marrying in secret without their parents' consent. The refugees were split in their opinion of how valid these marriages were. Several of them told me that some of the youth are genuinely in love, but because the family opposes the match, they elope. Others said the marriages were conducted mainly for resettlement purposes. However, it must be highlighted that the majority of those interviewed did not question the validity of marriages that had taken place with the consent of the family, whether the resettlement process was involved or not. Ronald, a forty-five-year-old married man who is often called to mediate marriages in his capacity as a community leader, said, "The UNHCR these days are saying many of our marriages are not legal, but they are. The couple, the relatives, the leaders and the priest all witness them."

Indeed, when I interviewed the Resettlement and Family Unity Officers ${ }^{27}$ at the UNHCR RO Cairo, they informed me that anecdotal statistics from a combined recollection of UNHCR staff from the year before showed that the number of marriages whereby both the man and women were recognized was only two. Both also commented on the high number of youth who "add on" a spouse after being referred for resettlement, and because of increasing concern about malfeasance in marriage practices around such unions, UNHCR Cairo had decided to stop adding spouses after a refugee had been recommended for resettlement. This policy undermines new spouses' entitlements to medical care, financial assistance, and vocational training opportunities.

Celsius, a thirty-two-year-old man who recently married after being referred to the American embassy for resettlement, summed up the many comments made by the refugees about the reasons for doing the "add on" after being referred for resettlement:

Well you finally have something to offer a girl. You have the prospect of supporting the needs of a wife and family. Sudanese parents will not allow their daughter to marry a man with no future prospects. The people abroad write back and advise our boys are to marry before traveling to America. If you go single you can't locate a wife there to marry. Besides, the income for one is very low and you need the income of two to live in America. Also, that society is not like our society where you can move from house the house for company. You need to marry someone from your own culture to understand you.
The parish priest of the Sacred Heart Church in Cairo, ${ }^{28}$ who in the past was responsible for writing all southern Sudanese traditional and church marriage certificates in conjunction with community leaders, shed some more light on the issue:

UNHCR recognition does not make refugees decide to marry. The Sudanese are socially obliged to marry. It makes them decide to marry at that point in their life. Many marry here in Cairo before leaving, as a wife will help them to live better in the West. It depends on the way they conduct the marriage that is the point whether it is real or not. If they try to escape the traditional process then the marriage is questionable. Most are solid marriages if done in the traditional manner. To make a marriage true in Sudanese culture is not the reason, but the process. Going through the family and cultural procedure makes it real.

\section{Cross-Cultural Marriage Partners}

Inter-ethnic and inter-religious marriage is often an indication of the level of tolerance and integration that has been achieved between two ethnic groups. ${ }^{29}$ Almost all of the refugees I interviewed said that marriage between southern Sudanese and Egyptians was impossible, due to their vast racial, cultural, and religious differences. However, Peter, a thirty-eight-year-old single man who also came to Cairo in the later 1980s on an educational scholarship, cited more economic and legal reasons for such marriages not taking place:

To marry an Egyptian girl you need to be able to buy a flat and pay for the Shabka [Arab dowry of gold jewelry]. We southern Sudanese do not have enough money this, and even if we wanted, we Christian men cannot marry Muslim girls, it's against the law in Egypt. Also if you marry an Egyptian you forfeit your right to be resettled, and although your wife is an Egyptian your children are refused the nationality.

In fact, Joanne, a thirty-year-old married woman with two children, was the only person interviewed who said she knew of a marriage between a southern Sudanese and an Egyptian:

I've heard only of one such marriage between the two groups. The case of a Dinka girl married with an Egyptian man. His family accepted and we were very surprised from this. Later on we heard she had been accepted for resettlement by the Australian embassy, and that the only reason he married her was to go oversees. The Australian embassy then told them to settle here in Cairo and now he has left her.

Joanne went on to tell me that almost every day when she goes to the bakery the men serving behind the counter ask 
her if she knows any Sudanese girls that would marry them, so they can travel to the West. The rift between the Sudanese and the Egyptian host society is being further exacerbated by the fact that African refugees are able to be resettled to the West, and poor Egyptians are not given the same opportunity. ${ }^{30}$

However, Godfrey remembers a time when relations were less strained between the two groups and some intermarriage did take place:

You know in the 80 's when students came to Cairo on scholarships to study at Egyptian universities inter-marriage was encouraged by the Egyptian government. They thought these will be the future intellectuals of Sudan, and if we encourage them to marry Egyptians then our interests will be looked after. You know the Nile water comes from the Sudan and the Egyptians are scared one day we will stop it. So at that time many northerners married Egyptians and even some southerners now that I recall. Now they no longer encourage marriage between us.

According to Fábos, prior to 1995, the Sudanese could enter Egypt without a visa, and were eligible for special status in residence, education, and employment laws. But since 1995, these rights have been slowly eroded. Marriage between northern Sudanese and Egyptians, previously a common occurrence, is now on the decline. This highlights how, in such a short space of time, inclusionary and exclusionary polices can affect intercultural relationships. ${ }^{31}$ It will be interesting to see if the Four Freedoms agreement is ever fully implemented whether intermarriage between the two groups recurs.

In addition to marriage with Egyptians, the refugees spoke about a new style of marriage that began emerging several years back, whereby Sudanese boys with UNHCR acceptance began marrying Ethiopian and Eritrean girls with closed files. Initially all of the refugees said that these were not genuine marriages, but "business" arrangements. Evidently, the girls paid for the privilege of being "added" to the file, and, once resettled, they divorced. Nonetheless, more than half of the participants at a later point in the interview said they knew of several that were "real" marriages. Most agreed that this practice has now died out, as the UNHCR and embassies have become very suspicious of such unions. "Some of the real marriages have fallen victim to false ones. I knew of one such couple that even had a child, but when they applied to the Australian embassy they were rejected," one of the refugee women told me. In fact this has become a major problem for Pita, a twenty-one-yearold Christian girl who is about to be resettled to America:
I'm accepted and I will travel soon, but my boyfriend is from Ghana and a Muslim. My family will not agree to the marriage. It has become very difficult for me to make the marriage and add him to my file. Even some of my friends keep asking is it a real relationship and I say yes.

\section{Transnational Marriage Partners}

There are a number of Sudanese men who, once they have resettled and established in the West, return to Cairo to marry. The refugees I interviewed cited several reasons for this practice. The importance of preserving Sudanese culture and identity through marriage with one's own group was mentioned by several of the research participants. Another, more practical reason given was the shortage of single young Sudanese women found in the West. This indicates that Sudanese refugee flows to the West are typical of most refugee resettlement patterns worldwide-male dominated, ${ }^{32}$ despite the fact that 80 per cent of the world's refugees are women and children. ${ }^{33}$

Besides the scarcity in numbers, the males interviewed went on to explain how Sudanese girls in Canada and America had been "spoiled" by Western ideals and culture and were no longer considered suitable marriage partners. Celsius told me:

There are problems with our girls there [in the West], they have become like the American girls. They are demanding and disrespectful. How much do you have in the bank they ask? Can you provide me with this and that and so on. Newcomers to America cannot meet all these demands. It is better to save and come back here to Cairo and find a wife who can balance your life, and that is why I chose one lady from Cairo to marry before traveling.

Lawrence, a twenty-seven-year-old man who had been resettled to America in 1998, returned to Cairo in June of 2003 to marry a "good girl" from his village, thereby reinforcing the community's perceptions. As he stood there in his American-style suit, adorned with gold rings (an alien concept to Sudanese men), speaking in a Texas accent, I heard him warn the men at his wedding reception: "Our girls have become too Americanized. In America the women have taken the role of the men, the men the women, and the children are the heads of the households." $\mathrm{He}$ pointed to his wife and advised the guests to take an "obedient" village girl. It turned out that his new wife had never actually been to her village in southern Sudan. She had been born in a displaced camp in Khartoum, and had been in Cairo for several years working as a housemaid, where she had obviously had to learn some tough survival strategies in negotiating the complex urban environment of Cairo. 
Lawrence failed to recognize that he himself had adopted certain aspects of the American identity, and also to realize that his wife is not quite the naive "village" girl he imagines.

Shandy's study gave a similar account of how Nuer men in America feel the women are too "corrupted" to marry. ${ }^{34}$ Yet, her study fails to incorporate the female perspective. This omission, as demonstrated by the female respondents in the present study, highlights the importance of incorporating gender roles and relations into our theoretical framework from the outset of our research. ${ }^{35}$ One lady said:

We hear the girls there are refusing our men. They know their rights and how to work for themselves. The men know that the [Sudanese] girls in America are intelligent, they know the banking and law system, and men have become afraid of their power.

The majority of the women interviewed were of the opinion that Sudanese women in the West were setting their sights on marrying the Kawaga [white man] or other Africans who are more established than the Sudanese newcomers, who will allow them more decision-making powers in the marriage and treat them with greater respect.

While they find it difficult to locate a suitable wife in the West, it appears that resettled southern Sudanese men are highly sought after by single young girls and their families in Cairo, in particular those with closed files. As Celsius stressed:

If there is a boy here who is not accepted and wants to marry your daughter, and along comes one who is already resettled, of course the parents are influenced by this. They are sure the one coming from America will take their daughter to a better place, and from there the daughter will send money to help them survive here in Cairo. This is what you would call a blessing for them.

Nonetheless, most of the refugees did not think that giving preference to these men was particularly dishonest. Mourto, a thirty-year-old refugee woman with three teenage daughters who has a closed file with UNHCR, summed up the majority viewpoint:

Life here for our young girls is very difficult. Many as young as 12 or 13 are working as maids in Egyptians houses and this is very dangerous for them, they could be beaten or raped at any time. The parents are desperate and have no way out but to send them to Egyptian houses to work. I have daughters of my own and when I think of their future life I cry. As parents we want to make sure our daughters will be safe and happy. Marrying your daughter to someone coming from the West is a way of escape from the life here.

\section{Dowry Payment and Marriage Ceremonies}

The dowry is the most important component of the nuptial process for all southern Sudanese tribes. The payment of the bride wealth (traditionally paid in heads of cattle) by the bridegroom's family to the bride's family validates the marriage with the principal objective of establishing the legal paternity of the future children. The dowry must always be paid, even partially, to legalize the marriage. ${ }^{36}$ Due to war, displacement, and dwindling cattle herds, Sudanese refugees, whether in America, Africa, or Egypt, have adapted to the new context by substituting money for cattle and adding cattle metaphors to their dowry calculations. ${ }^{37}$

Most of the refugees interviewed believed that the dowry system in Egypt was being further transformed as a direct result of the asylum-seeking process and third-country resettlement. The general viewpoint is that the dowry amount will not be reduced, but rather that the bride's parents will usually allow a boy who will be resettled to forgo paying the first instalment or to pay a token amount, with the promise of sending the remaining balance when he gets to the West.

The only occasion when the dowry is not paid is when the boy is marrying an Ethiopian or Eritrean girl. "Instead the girl will give money to the boy in order he adds her to his file. It's business," one lady told me. Nonetheless, she told me later on in the interview that "sometimes the couple might genuinely be in love and of course the girl will not pay in that case." Peter went on to explain how the money from such transactions is normally spent:

The boy usually gives it to his family to help them live here in Cairo. Or some send it back to their relatives in the camps in Khartoum to help them buy food and pay school fees. Even some use it to send to their brothers in Sudan to help them pay the dowry.

This statement was validated at a cultural celebration I attended in a displaced camp in Khartoum in August 2003. Three boys performed a play where they were all competing to marry the same girl, but none had money to pay the dowry. Two of the boys sought remittances from relatives in America. The third boy requested money from his relative in Cairo. To my surprise, it was the relative in Cairo who sent the money to the boy who won the hand of the girl. Perhaps this is because refugees in Cairo, due to their proximity to their homeland, still feel obliged to conform to cultural demands?

When I asked the refugees why Sudanese boys did not make such "business" arrangements with their own girls, Celsius, who is an accountant by profession, told me, "it's a matter of financial capital. Ethiopians are working with the dollar, and can earn $\$ 300$ to 400 a month, while Suda- 
nese are paid much less in Egyptian pounds." When I further probed as to why this was the case, Celsius, who is a relative newcomer to Cairo said, "I don't exactly know why." However, Peter, who has been in Cairo for many years, provided more insight into the reason behind this discrimination:

The Ethiopians have been here since 15 years and have built up a monopoly there in Maadi where the Kawagas [white men] live. They insisted on being paid in dollars from those Kawagas right from the very beginning. Also they have this system when one leaves they replace them with one of their own people. The Sudanese mostly work with the Egyptians who pay them much less.

There also appears to be a certain amount of racial discrimination involved in hiring Ethiopian refugees as opposed to their Sudanese counterparts. Pita related an incident that happened to her when she went for an interview with an Egyptian lady: "The lady told me in my face. You're too black, I prefer an Ethiopian who has lighter skin. They are less frightening for to the children." Pita went on tell me how absurd this was, as "the lady of the house was one of those ones Upper Egyptians and she was as black as me."

In fact, these claims are borne out by the results of a self-reliance study commissioned by the UNHCR in 2003 that showed that out of all of the refugee populations in Egypt, the Sudanese are paid the lowest salaries in relation to the amount of hours they work, while Ethiopians receive the highest income. ${ }^{38}$ This is a classical example of the ways in which refugee migratory flows are sustained by the social and cultural capital developed by refugees themselves. ${ }^{39}$

Conversely, if it is a single girl who has been accepted by UNHCR, the consensus among the interviewees is that the dowry price will be raised. One refugee man went on to give me an example of his conviction:

I know a Sudanese man who met the parents of the lady he wanted to marry and they agreed on the dowry payment. He then asked for a 2-week period in order to gather money from his family to pay the dowry. However, when he went back after 2 weeks to pay he discovered the figure had gone up. When the man asked why, they told him well now the lady has been accepted by UNHCR. So it really makes a difference because they say now the lady has the upper hand and she is the one that is going to travel and she is the one to add him to her file.

For this very reason, several of those interviewed in the study told me that a girl who is granted refugee status does not say anything to her family, as she knows they will demand a large dowry from the boy, and that if he can't pay they will refuse the match. Thus some are marrying in secret and traveling without paying the dowry. Interestingly, Baak, a fifty-sixyear-old community leader whose daughter tried to be "added" and travel without his knowledge, informed me:

Those boys who escape with your daughter without paying the dowry know they will eventually have to pay. We have developed networks with our leaders all over the West, and even in smallest village in Finland we can corner him for the dowry.

Evidently, the dowry price is always raised for those men coming from the West to marry in Egypt. Still, the refugees I spoke with did not think this unjust. As one of the interviewees put it:

Once a man comes from America or Canada to marry, the people say the man of the Western world has come with lots of dollars. So now one cow can go up to $\$ 100$, so many families ask to be paid 100 cows. He has to pay 30 cows up front and the remaining 70 they write on papers. If you come from the Western world they charge you uniformly. Each cow is worth $\$ 100$. Here in Egypt we ask 100 Egyptian pounds for one cow, so it is much less, but still uniformed. It is difficult for with those with closed files to pay even the 100 Egyptian pounds.

As well as the increased financial gain made from such matches, several of the research participants believed that a certain amount of community competition is attached to sealing these unions. Joanne, who is married to a Dinka man, told me, "in Dinka they give the girl to the man who brings the most cows. Now this has been replaced with UNHCR recognition and resettlement." Godfrey also remarked that even the man's country of residence in the West plays an important role in the proceedings:

They want them to be from America because they think this is the top country. In America they know there is money and this has raised the dowry price for such matches to be too much. America is the country that matters. It has become like a competition. Somebody came from America and married my daughter for such and such an amount. So when somebody else comes from America at a later date some parents will try and marry their daughter for a larger sum. My daughter is better. This is the mentality.

Then again, several of the refugees remarked that it is not just the problem of getting your daughter out of this country, but also of finding a good person to marry her. "The parents need to know the family. Is this man going to treat our daughter and sister well? It's not only about resettlement," one woman added. 
It must also be noted that marriage for competition to the highest bidder is not new to Sudanese culture. According to Deng, "bride wealth brings honor to the family, the greater level the cattle, the greater the honor." 40 Furthermore, one of the main purposes for paying the marriage dowry is to establish social alliances that will create new avenues of assistance that can be used in the event of future shortages. ${ }^{41}$ Also, as the dowry is shared between the bride's extended family, it is seen as a way of sharing wealth among the community. ${ }^{42}$ Thus, strategies employed by parents to marry their daughter to the highest bidder, and to the man that can provide the best future for her, are seen as a perfectly normal state of affairs for the southern Sudanese. Moreover, who is to say what is the more ethical, marrying for the greater good of the community, or marrying for individualistic gain, as some of the refugees I spoke to implied takes place in the West. Current ideologies of marriage in Western society equate love and romance with successful marriage, a perception obviously internalized by UNHCR Western staff and used when judging the authenticity of refugee marriage. Besides, can Western society really claim that economic factors do not come into play when it comes to choosing a marriage partner?

Nonetheless, when it comes to closed file cases, the community's sense of fairness is not always so evident. The majority of those interviewed said it was practically impossible for a single young man with a closed file to get married. One refugee woman described to me some of the tactics used by the parents to discourage a marriage to a boy with a closed file:

If the boy is rejected they ask for a huge dowry. They also ask for a church wedding followed by a big party. Of course he cannot afford to pay for this. What this actually means is that they are saying no to that man, but not outright.

Hence, it is not coincidental that the four men with closed file cases who took part in this study are still unmarried. They all lamented about the many difficulties they have faced while trying to persuade Sudanese parents to accept their dowry offer, but to no avail. All of the refugees interviewed talked about how not being able to marry causes many psychosocial problems among the youth. Peter elaborated:

Some of our boys, especially those with closed files are becoming drunkards, they drink this Aragi [Sudanese beer], and some even takes drugs. They can see no way out. They can't work, they can't get an education, and when finally they are rejected for marriage, it brings depression and a sense of hopelessness. Many are very angry and fighting for very small things.
I witnessed this for myself in April of 2003 when attending a traditional wedding. During the ceremony itself, a knife fight broke out between two subsections of the Dinka tribe over the marriage. The next day, according to the community members I spoke with, the dispute had gone transnational. Through the mobile telephone and e-mail their groups were fighting in Kukuma refugee camp in Kenya, in the displaced camps in Khartoum, and in Chicago, where many members of the same clan had been resettled. While a body of literature highlights the positive effects of transnationalism, very rarely does it discuss its detrimental effects. More research on this topic would add an invaluable new dimension to the transnational discourse.

\section{Marriage Ceremonies and Certificates}

Through participating in a number of Sudanese wedding ceremonies, I began to realize that most of the church ceremonies were taking place between couples who had been married traditionally for many years. Furthermore, most of these ceremonies were conducted several days prior to the couple's departure to the West. The majority of those interviewed believed that some of the couples genuinely wanted a "church blessing" to complete the union. The interviewees explained that in Sudan, the traditional ceremony is always carried out first, and the church marriage is conducted at a later date, when the entire dowry has been paid. In fact, the Sudanese refer to the church ceremony as the "the second part of the marriage." However, the refugees I spoke with also added that the resettlement process was beginning to influence the timing of this event and making it more popular among the community.

It seems refugees in Cairo see the church ceremony as one of a series of religious, social, and cultural events that have become part of the ritual of resettlement developed by the Sudanese. One refugee man told me in a very emotional voice:

We have the church marriage here so as we can have an African style service with our brothers and sisters beside us. So when we are resettled we show our children our marriage video and say to them this is your people, this is what you are-you are Sudanese.

Ronald, who was about to be resettled to Finland, added:

The ideal time to have the church ceremony is right before resettlement because you can join the African way, and the Western way. Since you are going to the West, and this is the Western system you have to adopt it right here in Cairo. 
In reality, my observations showed that the Sudanese seemed not only to have adopted African- and Westernstyled marriage ceremonies and customs, but also some Arabic traditions, such as decorating their hands with henna for the ceremony [although I suspect they would vehemently deny it given their aversion to all things Arab, as a result of the long civil war in Sudan between the Arab north and the African south] — a classical example of a "borderzone of multiple contextual identities." 43

I also suspect that the southern Sudanese use these many cultural events as instances of "resistance to exclusion and discrimination in a hostile environment." ${ }^{4}$

Although it is not legally the case, a few of the refugees were under the impression that a church marriage certificate was a UNHCR and embassy requirement. Without this document some believed they could not be resettled. Rumour also has it that a church marriage somehow helps refugees access employment, education, and social services in the resettlement country. One refugee lady remarked:

I believe the church marriage certificate helps you find jobs there, and also for us to admit our children into church schools, and for us to be accepted by the American and Canadian people as they are Christian countries.

By far the most talked-about stimulus for the church marriage is the refugees' perceptions, based on hearsay from the Sudanese diaspora, of how resettlement in the West is impacting Sudanese marriages. "Some couples do not trust each other and think the other will leave them when they are resettled," one man stated. This fear was voiced more by the male participants than the female ones. Celsius, who had recently married in church, summed up the many comments made by the male research participants concerning this subject:

Some [Sudanese] have the impression that when you go to the West having been married in church that it will bind your wife to you and prevent divorce. Sudanese men especially are afraid their wives will leave them because they hear that the Sudanese women in America have adapted quicker to the life there and that their husbands can no longer control them. There, if you just look at your wife in the wrong way she can dial 911 and the police come and take you away to prison. Our women are told this in the orientation classes here in Cairo. For these reasons, many of our men are insisting their wives marry them in church before leaving.

This emerging custom is a marked difference from traditional practice as, according to Deng:
Sudanese husbands feel it necessary to have a test period of married life before the marriage is confirmed with Christian celebrations. The wife, in turn, becomes insecure and apprehensive and tries to put pressure on the husband to marry in church. $^{45}$

Furthermore, some of the grievances voiced by most of the male respondents appear to be justified, given Duany's findings regarding her experiences with southern Sudanese refugees in America. The study claims that cultural orientation for Sudanese being resettled to America is not accurate or helpful. Evidently, some Sudanese couples find it difficult to understand and cope with the new setting, and without the support of their families and leaders, some women call 911 asking for assistance to solve their marital disputes, and on occasion the police believe it is an abusive situation and take the husband to prison. ${ }^{46}$ There is obviously a need to disseminate more accurate information to the refugee community in Cairo about UNHCR and embassy policy concerning marriage verification, and for the International Organization for Migration to ensure their cultural orientation curriculum is understood in the context of the resettlement country.

\section{Marital Life and Children}

Almost all of the refugees interviewed believed that RSD and resettlement procedures were causing many marital problems among the Sudanese refugee community in Egypt. As might be expected, most of the disputes seem to arise when a couple receives a denied result from the UNHCR. However, one of the refugees described how some of the martial discord emerging after rejection actually stems from the RSD application procedure:

Usually when newcomers arrive they go and take a form from the UNHCR office. The queue is very long and they only give out a set number of forms per day. After some days people get fed up waiting and because women are able to access the office more easily than men, often the women are the ones to collect the slips. So she becomes the main applicant, even if it is not her case. But when the result becomes negative, the husband accuses the wife of stealing his case and of being dull and of not talking well at the time of the interview. Each one starts to blame the other, some even insult each other and physically fight.

Attitudes regarding the severity and length of the marital conflict as a result of a negative decision varied among the interviewees. Deng, a 36-year-old married man with two children, reflected on his own marital experience on receiving a denied result: 
As a human being you should always have hope when looking into the future. So when you get rejected and you realize you will have to stay in Cairo you begin to see the kind of life that is in front of your children you lose hope. Also your wife keeps blaming you for the rejection. She talks and talks about it until you become short sighted and this is when the anger and violence comes. You know in Sudan women don't talk, but here in Cairo they are talking more than enough when it comes to UNHCR rejection. Because of this constant talking, I reacted very strongly to my wife and we fought for many days after we were rejected. We abused each other verbally and even we beat each other too much. After some time we calmed down and we both apologized and now things are good, now we have been accepted by the Canadian embassy for resettlement.

In fact, in a few extreme cases some of the marital fights initiated by a denied result have resulted in serious injury to one of the parties involved. The refugees spoke about the case of a wife who stabbed her husband with a knife when he told her they had been rejected by the UNHCR. Several refugees also cited a more extreme incident wherein a Sudanese man killed his wife because she was about to leave him for someone who was UNHCR accepted.

While the refugees agreed that most couples reconcile and stay together, as was the case with all of the married refugees who took part in this study, there was growing concern among those interviewed about the increase in alcoholism, domestic violence, and in some cases spouses leaving their partner for someone with UNHCR acceptance in order to be resettled.

Several of the refugees (both men and women) lamented about how men who have been abandoned and left to take care of their children in Egypt are not given the same priority by the resettlement embassies as women who are in similar situations. In the words of one refugee man:

A close friend of mine his wife left him after their file was closed and now the man is left here just moving around from house to house with his children. To my mind these men are not given the same consideration by the UNHCR office and resettlement embassies as women in the same situation. You hear of many of these women being resettled under the special program at the Canadian and Australian embassies, but I know several men who did not even get a reply.

This corresponds to some of the more recent literature on gender that claims that so much attention had been given to the plight of women that men are often ignored as gender beings when it comes to UNHCR and NGO policy. ${ }^{47}$

Finally, many of the interviewees were concerned about how the increased marital tension connected with RSD and resettlement was affecting their children. Ganniko, a twenty-seven-year-old married man with one son, who teaches at one of the informal refugee schools, narrated a story that reflected many of the sentiments voiced by the refugees on this subject:

One day I was walking around the school compound and entered into a classroom where the teacher had not arrived. I listened into a conversation between some of the children. We are traveling next year to Canada one said, Oh we are going to be added to the file of so and so and travel another said. One girl in the group said, we have been rejected and began to cry. You know even the very small children in the kindergarten use this UNHCR street jargon, Edafa [addition], Shakoushed [hammered - a term used by the refugees to mean closed file]. Sometimes I ask the children where is your father. They say my father was added to another woman's file and traveled. It makes the children upset and stressed and sometimes they become psychologically ill from all of this UNHCR and resettlement talk.

\section{Family Planning Decisions}

Traditionally, the Sudanese believe the purpose of marriage and sexual relations is to beget children. The success of a Sudanese marriage in judged by the number of children a couple produces. Hence, Sudanese woman are expected to become pregnant directly after marriage. If she fails to conceive the husband has the right to divorce her or take another wife. ${ }^{48}$ According to Bates these Sudanese cultural values naturally oppose birth control. ${ }^{49}$ Only two of the males interviewed said that RSD and resettlement had no influence on such decisions, it was according to the couples' own traditional and religious beliefs. Still, it is important to note that these men are single and have little insight into the family planning strategies of Sudanese couples. In fact, most of the refugees I interviewed agreed that RSD and resettlement processes were playing a significant role in altering family planning practices among Sudanese in Egypt. It seems couples can make quite radical family planning decisions based on their understanding of how RSD and resettlement operate. "There is a rumor that the American INS lawyers favor married couples with children and this is the very reason why my cousin got pregnant," Joanne told me. Godfrey, in his capacity as a medical doctor, gave quite an extreme example of how such rumours can sway a couple's decision:

I know of a girl who came from the Sudan and applied to the UNHCR. In the meantime she got married and became pregnant. The community advised her not to inform the UNHCR she was pregnant. The people [Sudanese] told her your husband 
was rejected by the UNHCR a long time ago. If you tell UNHCR the truth, and they discover your husband has a closed file, they will reject you. You know the people say it is better for a girl to be single, you can be accepted under this single women category. So they came to me for medical advice, and as much as I tried to dispel this belief, they went to a clinic and they aborted the child. Luckily she was ok as this is a dangerous procedure here in Cairo. Later she was accepted by the UNHCR and added the husband and they traveled.

The general consensus among the interviewees was that those with closed file cases are postponing having children, while those with UNHCR recognition continue to have as many children as they want. However, there are some exceptions to the rule, as one refugee lady pointed out:

If the woman is the one working and it is her case they were accepted under then she can refuse to have more children, even if the husband wants to continue. He cannot insist. He is afraid she will get angry and ask him to leave the house and then what will he do without any money? She might even decide to divorce him and add someone else to her file. So he keeps quiet.

Achol, a 42-year-old married woman who works as a health practitioner at one of the refugee health clinics in Cairo, also suggests that the timing of a pregnancy is an important aspect for those being resettled:

A pregnancy can delay the resettlement process as you have to take time to make the new addition to your file so some couples are reluctant to have children near the scheduled departure date. I had a lady in my clinic that was kept here in Cairo for nearly 3 years because of all the delays caused by the $11^{\text {th }}$ of September attack. In the meantime, she got pregnant and this further delayed the process. The husband was so angry because the pregnancy delayed them even more that he beat her.

Evidently this is a marked change from traditional Sudanese values, whereby it is considered a disgrace for a man to beat his with wife because of her reproductive importance. ${ }^{50}$

Undoubtedly, family planning becomes more of a concern to those without UNHCR recognition. Baak, who is often called upon in his capacity as a community leader to mediate in marital disputes about family planning, summed up the many comments made by the refugees concerning birth control in relation to closed file cases:

Some couples who are wise will stop having children because in Egypt the women are the ones working, while the men stay home looking after the children. We already struggle to pay the rent and feed our children. Bringing another child will only bring more financial problems. Also men can't look after small babies. The husband sometimes has little say in the marriage now, because it is the women who are making the money and they have a much stronger voice in family planning matters. Also, the health clinic only helps those with closed files for one pregnancy, after that no more assistance. It's the China policy. That's why we men are forced to accept contraception, especially if there are no prospects of resettlement."

Still, a few of the refugees remarked how the decision to use birth control was not always an amicable one. Joanne described her own experience on receiving a denied result:

When we got rejected, I wanted to use contraceptives, but my husband refused for religious reasons. So I said to him you go to the other bedroom then, and he agreed to this. But not all men accept such things. Some of our men are still refusing to practice family planning even though they have a closed file. You know they went there to the clinic and fought with the medical staff. They said to them you are the ones giving our wives pills and we don't want these things.

What's more, Mourto once again talked about the concerns she had for the future of her children and highlighted that the decision not to have children is not entirely based on financial needs:

Every day the Egyptians are shouting Bonga [name given to a chimpanzee in an Egyptian TV program] and Samara [Black] and spitting at our children on the street. There is no safe place for them to play. There is no future for their education. Some leave school at a very young age to work in Egyptian homes where they can be treated badly. If we complain to the police they do nothing about these cases. Instead they take you to prison for not having the legal residency. Even the police take our children from the streets. In January of this year [reference to Operation Track Down Blacks] they took women and children from the street and some stayed in prison for two weeks before being released. Our children are psychologically damaged from all of this bad treatment. I said to my husband when we got rejected, it's better not to bring more children. I can't watch them suffer like this.

\section{Divorce and Remarriage}

Apparently, divorce among the southern Sudanese is a very rare occurrence, as marriage is seen as a political institution and not a function of romance or sexual desire. ${ }^{51}$ However, many of the refugees interviewed said that divorce was on the increase among the Sudanese refugee community in Egypt. Although a closed file and all the hardships that 
accompany it can eventually lead a couple to divorce, another catalyst for divorce among the refugee population appears to be the refusal of Western countries to resettle refugees who are in polygamous marriages. As one refugee man succinctly put it:

The resettlements embassies run along Western lines. The oneman one-wife concept prevails. Men are forced to choose only one wife to add to their file, and are obliged to divorce the others in order to be resettled. For sure this causes many families to break-up.

There seems to be no set pattern as to which wife the husband chooses to "add" to his file. Some take the youngest wife, while others choose the eldest wife. Apparently others add the one they have the most affection for. The refugees I interviewed described the different strategies adopted by the family to try to get the other wives added to file in order that they can be resettled with the rest of the family. Some men register the elder wife as their legal spouse and the younger as a daughter. Others try to add their wives as dependent sisters. As this approach is not always so successful, some will divorce and the wives will open their own file at the UNHCR and the embassies. The refugees were aware that these strategies were dishonest, but in their opinion they had no option but to lie, given the harsh living conditions and high levels of racism encountered on an almost daily basis on the streets of Cairo.

As might be expected, the question of which wife and children to "add" becomes a contentious issue. Achol, who regularly counsels women in the health clinic that she works at, described the factors that come into play when making such a decision:

It's a problem for the man as he has to do what is best for the family long term, and at the same time he feels accountable for the other wives and children left behind. Sometimes he takes the elder wife, sometimes the youngest one. Some of the wives fight of course, but they usually agree for the sake of the children. The relatives and community leaders start getting involved and make the wives agree. What the community recommends is that all the children from all of the wives be added to the file. You know it is our custom for the father to have custody of the children. Sometimes there are too many children and the UNHCR will become suspicious so in that case some of the younger children stay with the mother while the older ones go as they can work there and send money back.

Several of the refugee women who spoke with me added a new aspect to the community leaders' role in "persuading" the wives to conform. They claimed that in the dis- placed camps in Khartoum they were often called to participate in the community councils to solve marriage disputes, but now in Cairo they have been excluded. The reason given by the women for this change in custom was that most of the community leaders have more than one wife and they don't want the women to be party to the discussions and decisions made in the community councils in Cairo lest it jeopardize their resettlement chances. In the setting of Khartoum, resettlement was not an option, and it was in the man's best interests to stay married to all his wives because of their combined earning potential. These findings tie in with Abdulrahim's study, which showed how in the new context of Berlin, Palestinian women were returned to a more conservative way of life, in contrast to the freedom of movement and voice they had left behind in the refugee camps in Lebanon. What's more, the practice of polygamy, which had virtually died out in the camps in Lebanon, became more common in the context of Berlin where Palestinian men began to take German women as second wives in order to guarantee citizenship. ${ }^{52}$

While most of the interviewees said that the husband and wives will finally come to an agreement regarding who is to be "added," a few mentioned that some women will go to the UNHCR and embassies to complain, as happened in Natalina's case:

My husband chose to add me to his file and we were supposed to travel to Finland, but the other wife became mad from this and caused many fights in the house. She went to the UNHCR office and sabotaged the whole case and we were told to settle here in Cairo. But now she regrets this when she sees the suffering of her children.

In the meantime, Natalina's husband divorced her and she applied to the UNHCR and was denied status, but has since been accepted by the Australian embassy for resettlement under its single women at risk program. It must be stressed, however, that this process can take several more years, and not all of these women are fortunate enough to be resettled.

The refugees I met with talked at great length about the difficulties that the wives left behind face living on their own in Cairo. Ironically, Natalina, who complained bitterly to me about the other wife "sabotaging" her case, went on to describe the many problems these women have to contend with:

Because the husbands did not add them to their files they don't get any money from UNHCR. Most work as day maids with Egyptians, but the salary is very little and many of these husbands are not sending money back. If they don't have any 
relatives in Cairo she has to lock the children in the apartment and go to work. This is very dangerous for the children and many have had accidents. I know one eight year old girl who was left caring for a baby and she tried to heat milk to feed the baby and it fell on the baby and burnt it very badly.

Several of the research participants said that most of these women take the oldest girl out of school to take care of the younger children as they do not have time and money to send all the children to school. This corresponds to Dingemans's study that linked poor attendance of Sudanese refugee children from one-parent families with poor school attendance. ${ }^{53}$

The physical and psychological effects of leaving children unsupervised were discussed at great length by the interviewees. One refugee man revealed how being locked inside for long periods of time can affect child development:

One woman I know locked her children inside every day for a year. These children were psychologically disturbed, misbehaving and crying all the time and throwing themselves on the floor and urinating on the floor. I witnessed this myself and it was disturbing to see.

Achol also cited another more extreme example of a child who presented at her health care in urgent need of emergency medical treatment:

One woman in Ain Shams [district of Cairo] who was left here with her children while the husband traveled to America with the other wife was locking her children inside when going to work. One day two Egyptians came and asked the children to open the door. They sent the oldest boy to get them something from the shop and when he went they raped the girl and she was only 8 years old. The mother could not go to the police as she has no legal papers and they might deport her or put her in the prison. The Sudanese know the police will do nothing about these cases.

Some of these women eventually have to resort to prostitution or the selling of aragi [Sudanese beer] in order to make a living. Still, brewing illegal alcohol is not without problems. In the words of one refugee woman: "Some of these drunkards who come to buy aragi can beat the women and her children. The Egyptian police ask for tips and sometimes sexual favors from the women, and if they refuse, they take them to prison." Nearly all the interviewees spoke about the rape of two Sudanese women, one of whom was four months pregnant, by a gang of Egyptian men, which had taken place in an apartment in Cairo in 2002. Apparently, these women were brewing and selling alcohol and the men were able to enter their apartment on the pretext of wanting to buy beer. Because these women were closed files with no legal residency they did not report the incident to the police. Seemingly, many of the women left behind eventually remarry for protection reasons.

According to the refugees interviewed, a good number of these women are eventually resettled under the humanitarian program, often under the women-at-risk category of one of the resettlement embassies. Moreover, most of these cases have been processed twice at great financial cost to the UNHCR and resettlement partners. However, the biggest cost has been the human suffering borne by the refugees themselves, in particular women and children. Interestingly, some of these women are eventually reunited with their husbands and continue to live in a polygamous marriage in the West whether it is legal or not.

\section{Concluding Remarks}

The findings of this study show that RSD and third-country resettlement have played a significant role in influencing the marriage practices of the southern Sudanese refugee community in Cairo. Lack of local integration prospects and the increasing insecurity of the city of Cairo for refugees have caused many Sudanese to resort to extreme measures, even fraud, in order to be added to a UNHCR-recognized file through marriage to qualify for resettlement. Although these measures have allowed some refugees to escape to a better life in the West, they have also negatively impacted marital and family relations. There is an urgent need for Egypt to withdraw its reservations to the Refugee Convention to allow refugees to be able to attain a greater level of socio-economic integration into Egyptian society.

Furthermore, UNHCR and resettlement embassies in Cairo should realize that:

fraud occurs because of lack of opportunities for refugees. If local integration were a real possibility for a larger number of the world's refugees, we would expect to see less fraud around resettlement. Resettlement is not just an option-it is an urgent escape route to safety and dignity. ${ }^{54}$

The findings highlight yet again the extreme vulnerability of urban refugees, and in particular those with closed files cases. The study also shows how refugees' perceptions and understandings of how the RSD and resettlement processes operate, based on hearsay and rumour, can drastically alter the behaviour of some couples. There is an obvious need for the UNHCR to disseminate clear and accurate information concerning its operations to the refugee community. The refusal of Western embassies to accept refugees for resettlement who are in polygamous marriages is 
another policy that needs revising, especially given the fact that many of the women left behind in Cairo from polygamous marriages eventually end up being resettled to countries where the practice of polygamy continues, whether it be among the recently arrived refugee community, or among Mormon citizens as is the case in America.

In addition, this research gives many examples of the different needs and vulnerabilities of both southern Sudanese refugee men and women in the context of Cairo. This underlines not only the importance of incorporating a gender dimension into research studies from the outset, but also the necessity for a proper gender analysis of the context and situation, in order to ensure that the RSD process and assistance programs are gender sensitive. Indeed, Obi and Crisp in their study of urban refugees in New Delhi recommended that the new urban policy be based on the principles of "People Orientated Planning." ${ }^{5}$ Nonetheless, it must be highlighted that the actual design of the POP gender training and analytical framework must be examined in relation to gender discrimination in the RSD process and assistance programs. According to March et al. one of the main downfalls of the POP framework is that it looks at what men and women do separately, rather than concentrating on the relationship between them-ignoring men as gender beings. ${ }^{56}$ If this is the case, it might be better for a more appropriate gender analysis tool to be designed and adopted by UNHCR and NGOs.

More extensive studies that incorporate the different transnational experiences of refugees living in the displaced camps in Khartoum, the urban environment of Cairo, and those resettled in the West would provide a more in-depth comprehensive picture of the extent of the influence that RSD and third-country resettlement are having on southern Sudanese marriage practices. Furthermore, studies that look at both the positive and negative aspects of transnationalism in relation to marriage would also add further insight into the debate and complement existing refugee literature.

\section{Postscript}

In the last quarter of 2005, some three thousand Sudanese refugees and asylum seekers began a three-month long sit-in at a public park near the UNHCR office in Cairo. The protestors rejected voluntary repatriation and local reintegration as durable solutions on the grounds of the continuing political instability in Sudan, in particular Darfur, and their inability to attain a sustainable livelihood and access to basic services in Egypt, and sought resettlement to a Western country. On December 30, 2005, the protest was ended by the forcible removal of the protestors by five thousand Egyptian riot police. During the evacuation of the park twenty-seven persons were killed (including twelve children) and many more were injured.

\section{Notes}

1. Refugees in Cairo do not enjoy many socio-economic rights provided for by the Refugee Convention partly due to Egypt's reservations to some of the key provisions of the Convention, namely Articles 12 (1) (Personal Status), 20 (Rationing), 22 (1) (Public Education), 23 (Public Relief) and 24 (Labour Legislation and Social Security). A refugee's right to work is regulated by Egypt's foreign employment law. Employers must obtain a work permit to legally employ a refugee, as for any foreigner. A permit is very expensive and is only granted if no Egyptian is found to fill the post. As Egypt's unemployment rate is running at 20 per cent, it is practically impossible for a refugee to find work in the formal sector and be granted a work permit. In my ten years' experience of working with refugees in Cairo, I only ever met one refugee who was granted a work permit.

2. The January 9, 2005, peace deal between the Sudanese government and the Sudan People's Liberation Army ended Africa's longest-running civil war and created high hopes for refugees from southern Sudan living in neighbouring countries to return. The continuing instability and lack of infrastructure in southern Sudan and the present violence in Darfur have meant refugees have been reluctant to return. The number of refugees repatriated from Egypt to Sudan in 2005 was only sixty-five.

3. A "recognized refugee" is a person who has been accepted by UNHCR or a government to meet the refugee definition. "Asylum seekers" are persons applying for recognition of their status as refugees. "Closed file" or "rejected file" refers to asylum seekers whose applications have been denied refugee status by UNHCR at the first instance interview and on appeal and are therefore no longer considered under the protection of UNHCR. At the time of this study, the refugee community perceived UNHCR recognition as being linked to resettlement, as RO Cairo mainly used the 1951 definition of a refugee in its RSD process. Thus most of those recognized as refugees were eligible for resettlement. In April 2003, UNHCR decided to apply a wider interpretation of the OUA Convention definition. Now, those accepted under the Refugee Convention definition are eligible for referral to a resettlement partner, while those accepted under the OUA definition are locally resettled, as the resettlement countries are not parties to the OAU Convention and do not accept refugees who fall under this Convention for resettlement.

4. Snowball and opportunistic sampling were used to select research participants. Some elements of quota sampling in terms of age range, gender division, tribe, and marital and UNHCR status were also introduced. The in-depth interviews lasted on average ninety minutes and were conducted in English, Sudanese colloquial Arabic, Juba Arabic, and Balandi. Of the twenty-two research participants, fourteen were men and eight were women (from different tribes and religions). Also, 
thirteen were married, five were single, four were divorced, and three were in polygamous marriages. As well, eleven were recognized refugees, five were asylum seekers, and six were closed file cases. It is important to note that findings in qualitative studies cannot be generalized to other populations or even to the wider population from which the sample is drawn, but as displacement is a shared experience, it is feasible to make some valid observations about the impact RSD and resettlement are having on southern Sudanese marriage practices.

5. UNHCR Egypt Statistical and Country Reports 2005. These figures do not include the seventy thousand Palestinian refugees who are registered with the Egyptian authorities and are of concern to UNHCR.

6. S. Sperl, "Evaluation of UNHCR's Policy on Refugees in Urban Areas: A Case Study Review of Cairo," Geneva: UNHCR Evaluation and Policy Anaylsis Unit, 2001/07, 1-59, <www. unhcr.ch> (accessed March 2, 2003).

7. UNHCR Cairo Country Report 2005

8. "Information Booklet for Asylum Seekers and Refugees in Egypt," (UNHCR, 2003), 1-15.

9. C. Johnston, "Egypt's African Migrants Dodge Rocks and Fight Racism," Reuters, June 24, 2002, <http://mafhoum. com/ press3/103S21.htm $>$ (accessed February 1, 2003).

10. M. Kagon, "Assessment of Refugee Status Determination Precedure at UNHCR's Cairo Office 2001-2002," Working Paper No. 1, Forced Migration and Refugee Studies, American University in Cairo 2002, 1-49; <www.aucegypt.edu/fmrs> (accessed April 7, 2003).

11. H. Fábos, "Marriage, Sudanese-Style: Transnational Practices of Citizenship and Gender-Making for Sudanese Nationals in Egypt," North East African Studies (New Series) 8, no. 2 (2001): 277-301. Up until 2004, Egyptian citizenship was a gendered phenomenon. Fathers alone had the right to transfer citizenship. Now Egyptian women can pass on their citizenship to their children.

12. UNHCR Egypt Country Report 2005.

13. Sperl, 15.

14. "Information Booklet for Asylum Seekers and Refugees in Egyp," 4.

15. J. Lejukole, "Changes in Family Gender Roles among the Southern Sudanese Families in Cairo" (master's thesis, Department of Anthropology, American University in Cairo, 2002).

16. S. Negas, "When Is a Refugee Not a Refugee?" Cairo Times, Vol. 1, Issue 1, March 6, 1997. Note that the fear of deportation overrides the reality as the majority of asylum seekers and closed-files cases are not actually deported.

17. Sperl, 22.

18. "Fact Sheet," Bureau of Population, Refugees and Migration, United States Department of State, 2001; <http://www.state. gov/g/prm/rls/fs/2001> (accessed March 1, 2003).

19. N. Azimi, "Caught in Limbo," Al Ahram Weekly Newspaper, Issue No. 611, 7-13, November 2002.

20. Sperl, 4
21. African Refugees Targeted in Cairo, Egypt," Human Rights Watch, February 10, 2003; <http://www.africanonline.com/ site/Articles $>$ (accessed March 1, 2003).

22. "The Flood of Africans and Asians Who Steal the Bread from the Mouths of Our Unemployed Youth," Rose El Yussef Newspaper, January 11-17, 2003, 26-28.

23. Sperl,12.

24. Johnston, 1.

25. J. K. Edward and B. N. Duku, "Redefining Gender Roles and Relations in Exile in Sudanese Cultural Digest Project," in Coping with Dynamics of Culture and Change: Sudanese Refugees in East Africa and Internally Displaced Persons in Southern Sudan, Research Report No. 2 (Cairo: American University in Cairo Press: 1998).

26. Ibid.

27. Personal interviews with the Resettlement Officer and Family Unit Officer, UNHCR RO Cairo, July 23, 2003.

28. Parish priest of the Sacred Heart Church in Cairo, personal interview, June 14, 2003.

29. Edward and Duku.

30. L. Ashton, "Egypt's Treatment of African Asylum Seekers Is Ambiguous, Middle East Times, February 2003, 15-21.

31. Fábos, "Marriage Sudanese-Style," 278.

32. S. Castles and M. Miller, The Age of Migration (Hampshire: Palgrave, 1998).

33. A. Callamard, "Flour Is Power: The Gendered Division of Labor in Lisongwe Camp," in Development and Diaspora: Gender and the Refugee Experience, ed. W. Giles, H. Moussa, and P. Van Esterik (Toronto: Artemis Enterprises, 1996.)

34. D. J. Shandy, "Transnational Linkages between Refugees in Africa and in the Diaspora," Forced Migration Review 16 (2003): 7-8.

35. A. H. Fábos, "Dilemmas of Urban Research in Africa" (paper, presented at the workshop Methods and Ethics in Studying Refugees in Urban Environement, American University in Cairo, April 11, 2003).

36. F. M Deng, Tradition and Modernisation: A Challenge for Law among the Dinka in Sudan (New Haven and London: Yale University Press, 1971); S. Hutchinson, Nuer Dilemmas: Coping with Money, War and the State (Los Angeles: University of California Press, 1995).

37. E.B. Rackley, "Displacement, Conflict, and Socio-Cultural Survival in Southern Sudan," Journal of Humanitarian Assistance (2000), 1-13, <http://www.jha.ac/articles/a056.htm> (accessed April 10, 2003; Shandy, 8.

38. UNHCR Refugee Self Reliance in Cairo: Obstacles and Prospects (Cairo: Palm Press, 2003).

39. Castles and Miller, 25.

40. Deng, 143.

41. Rackley, 8 .

42. L. T. Eman, "Jieng (Dinka)," in A Concise Study of Some Ethnic Groups in Sudan, Research Report No. 1 (Cairo: American University in Cairo Press, 1996).

43. Fábos, "Dilemmas of Urban Research in Africa," 3.

44. Castles and Miller, 37. 
45. Deng, 90.

46. J. K. Duany, "Special Needs of Sudanese Girls," 2001, $<$ http://southsudanfreisns.org/specialneeds > (accessed November 3, 2003).

47. S. Turner, "Angry Young Men in Camps: Gender, Age and Class Relations among Burundian Refugees in Tanzania," Working Paper No. 9, New Issues in Refugee Research, UNHCR, 1999, <http://www.unhcr.ch> (accessed July 24, 2003); J. El Bushra, "Gender and Forced Migration" Forced Migration Review 9 (2000), 4-8.

48. Deng, 98.

49. D. Bates, "Health Beliefs of Sudanese Refugees" (master's thesis, Texas Woman's University, 1996), cited in "Sudanese Culture, Health and Refugees (2000), <http://www3.baylor. edu $>$ (accessed November 23, 2003); Hutchinson.

50. Duany.

51. Ibid, 2.

52. D. Abdulrahim, "Defining Gender in a Second Exile: Palestinian Women in West Berlin, in Migrant Women Crossing Boundaries and Changing Identities, ed. G. Bujis (Oxford: Berg, 1996).

53. E. Dingemans, "Educational Needs and Priorities for Southern Sudanese Refugees in Cairo" (unpublished field report, submitted to Forced Migration and Refugee Studies Department, American University in Cairo, 2002).

54. M. Hertfield, "NGO Statement on Resettlement: Global Consultations on International Protection" (Geneva: UNHCR, 2002), <http//www.refugeecouncilusa./org/ngoresetst> (accessed February 12, 2004).

55. N. Obi and J. Crisp, "Case Study of New Delhi" (Geneva: Evaluation and Policy Analysis Unit, UNHCR, 2000/04, 1-46), <http://www.unhcr.ch> (accesed March 2, 2003).

56. C. March, I. Smyth, and M. Mukhopashyay, A Guide to Gender Analysis Frameworks (Oxford: Oxfam Publications, 2000).
Lorraine Currie has an M.A. in refugee studies from the University of East London and an M.Sc. in international health from Queen Margaret College University in Edinburgh. She is presently a senior public health program manager working in northern Uganda. Prior to her current position, she worked in Cairo with African refugees (mainly southern Sudanese) managing advocacy, assistance, education, and health projects for refugees. 